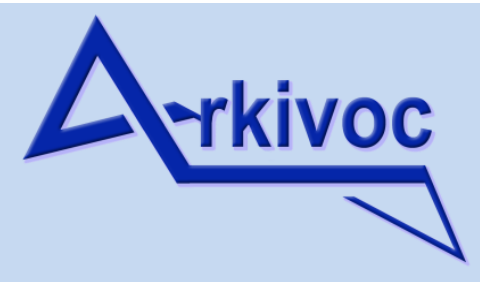

Archive for

Organic Chemistry
The Free Internet Journal

for Organic Chemistry
Paper

Arkivoc 2018, part iv, 215-230

\title{
Synthetic studies toward the total synthesis of aeroplysinin
}

\author{
Gennadii A. Grabovyi and Justin T. Mohr* \\ Department of Chemistry, University of Illinois at Chicago, 845 West Taylor Street, Chicago, \\ Illinois 60607, United States \\ Email: jtmohr@uic.edu
}

Dedicated to Prof. Dr. Gordon W. Gribble on the occasion of his retirement from Dartmouth College

Received 01-21-2018

Accepted 03-24-2018

Published on line 04-21-2018

\section{Abstract}

Herein is described an expedient and highly efficient synthesis of 2,4,4-tribromo-6-hydroxy-3-methoxy-6(cyanomethyl)cyclohex-2-en-1-one, a densely functionalized polybromide that is a potential precursor to the halogenated antibacterial and anticancer natural product aeroplysinin. The developing synthetic sequence enables preparation of the target polybromide in a good yield in five steps from cyclohexane-1,3-dione without using any protecting groups. The approach highlights recent developments in remote halogenation reactions using conjugated anionic intermediates.

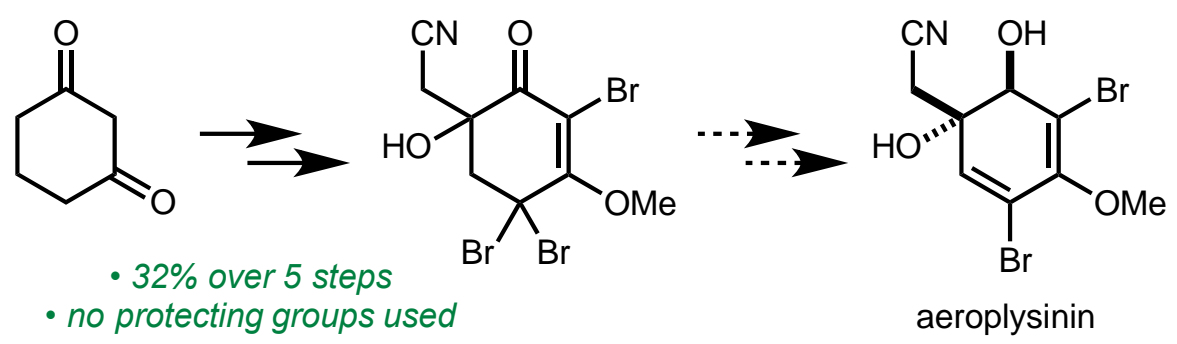

Keywords: Total synthesis, aeroplysinin, halogen, bioactive, natural product 


\section{Introduction}

Halogenated natural products remain an intriguing and important class of molecules with varied biological activities and structural characteristics that continue to inspire new synthetic techniques. ${ }^{1,2}$ The highly functionalized, bromine-containing marine natural product aeroplysinin (1) was isolated independently in 1970 by the groups of Sodano and Mills from Caribbean sponges lanthella ardis and Verongia aerophoba. ${ }^{3,4}$ It was shown that aeroplysinin is used by sponges as a chemoprotective agent against invasion of bacterial pathogens after external tissue injury. ${ }^{5}$ Interestingly, both enantiomers show a number of promising biological features such as high in vitro cytotoxicity toward HeLa cells and antibiotic activity against Bacillus subtilis, Staphylococcus aureus, and Escherichia coli. ${ }^{4-7}$ Decades after being reported for the first time, the biological properties of aeroplysinin experienced a major addition; recent studies showed that aeroplysinin also inhibits human endothelial cell angiogenesis thereby suggesting that this metabolite may be useful as a angiogenesis inhibitor, or a cancer, atherosclerosis, and inflammation-dependent disease treatment. ${ }^{8,9}$

a)<smiles>COc1c(Br)cc(CC#N)c(O)c1Br</smiles>

2

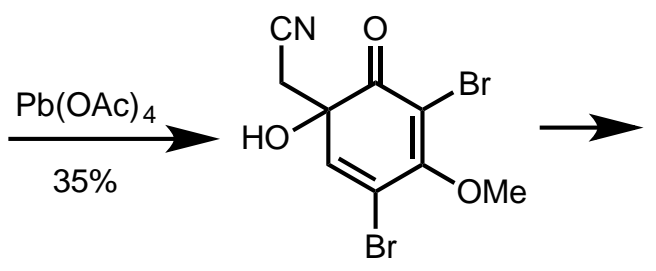

3<smiles>COC1=C(Br)C(O)[C@](O)(CC#N)C=C1Br</smiles>

aeroplysinin (1)

b)

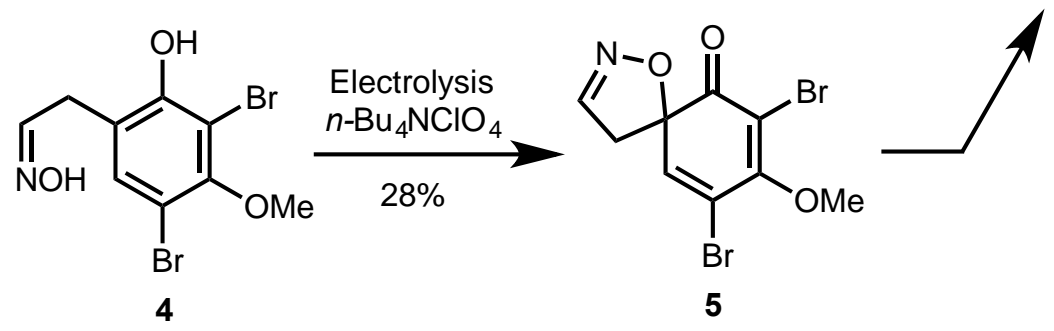

Scheme 1. Andersen's (a) and Nishiyama's (b) approaches to aeroplysinin (1).

The first total synthesis of aeroplysinin was developed by Andersen ${ }^{10}$ and employed lead tetraacetatepromoted oxidation of functionalized aromatic cyanide $\mathbf{2}$ to dibromodienone $\mathbf{3}$, which was then diastereoselectively reduced to the desired natural product $\mathbf{1}$ (Scheme 1, a). Waldmann and co-workers have used this robust route for evaluation of several structural analogues. ${ }^{11}$ Another synthesis was devised in the group of Nishiyama ${ }^{12,13}$ and incorporated transformation of oxime 4 under electrolytic conditions into spiroisoxazoline 5, which was then reduced in two stages to generate aeroplysinin (1) (Scheme 1, b). Despite the relative brevity and simplicity, both approaches suffer from modest yields and employ relatively harsh oxidative conditions to achieve dearomatization, thus making the task of developing a short, mild, and efficient synthesis of aeroplysinin a continuing challenge. 


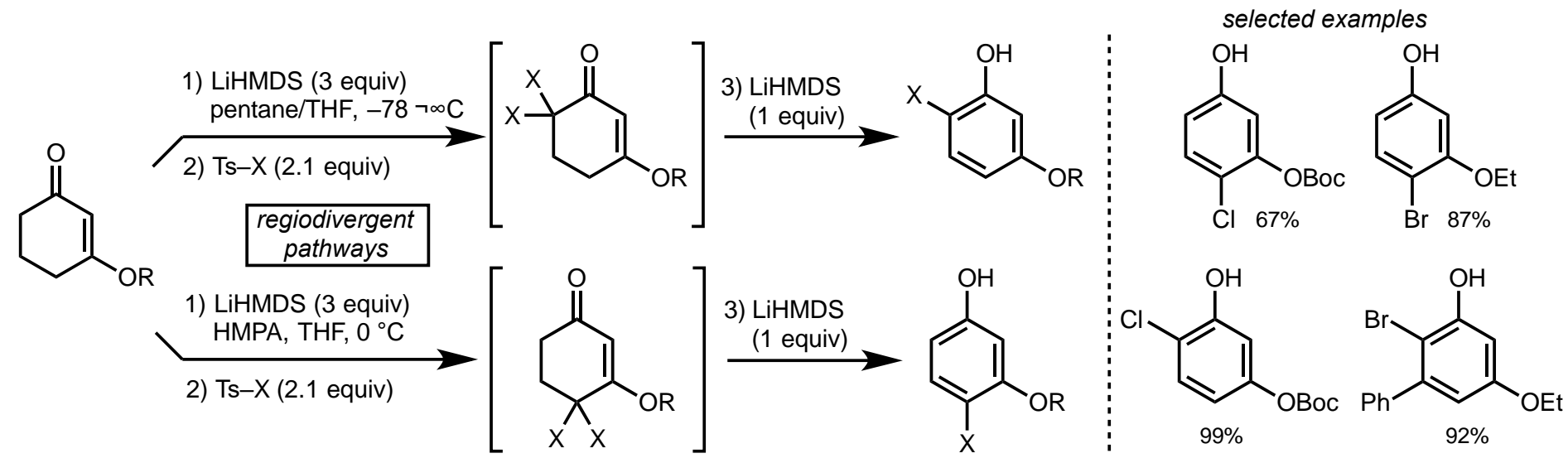

Scheme 2. Regiodivergent synthesis of halogenated aromatics.

Recently we reported an efficient method for the regiodivergent synthesis of halogenated resorcinol derivatives using readily available vinylogous esters and common electrophilic halogen sources as starting materials (Scheme 2). ${ }^{14,15}$ We have also demonstrated the utility of this methodology in natural product synthesis. ${ }^{16}$ In the course of our studies we found that by limiting the amount of base present during the reaction, the postulated dihalogenated vinylogous ester intermediates could be isolated and independently aromatized upon exposure to additional base. We hypothesized that this observation regarding the reaction pathway was well suited to the development of a synthetic route to aeroplysinin (1) that would employ latestage dibromination/elimination of a preliminarily functionalized vinylogous ester. This strategy would differ from the reported dearomatization approaches and make use of regioselective functionalizations of anions derived from vinylogous esters, which is a focal point of our research program. ${ }^{10,11}$ We also hoped to gain further insight into novel approaches to halogenation reactions, which is also an area of interest in our group. ${ }^{10,11,18,19}$ Herein, we report the results of our synthetic endeavors to-date.

\section{Result and Discussion}

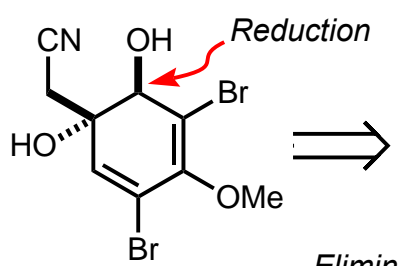

aeroplysinin (1)

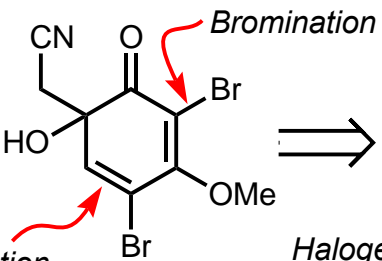

3

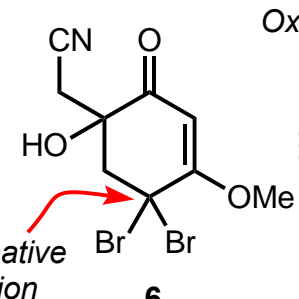

6

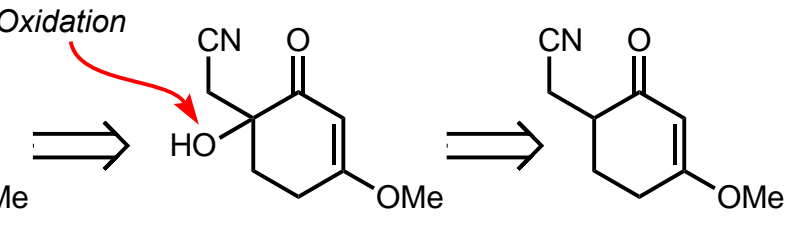

7

8

Scheme 3. Retrosynthetic analysis of aeroplysinin (1).

To achieve our goal we devised a strategy in which the desired diol functionality in the natural product (1) could arise from the precedented ${ }^{8}$ reduction of dibromoketone $\mathbf{3}$ (Scheme 3 ). The dienone $\mathbf{3}$ was, in turn, envisioned to be available from the gem-dibromide 6 as a result of $\alpha$-bromination and elimination to form the $\gamma, \delta$-unsaturation, an idea buoyed by recent work by Hamme $\mathrm{II}$ and co-workers. ${ }^{20}$ Compound 6 could be generated from functionalized $\alpha$-ketol 7 via our novel halogenation methodology. ${ }^{10,11}$ Whereas vinylogous ester 7 lacks labile $\alpha$-protons adjacent to the carbonyl, the formation of gem-dibromide 6 followed by addition of an 
extra equivalent of base would not lead to substrate aromatization but rather simple elimination. The $\alpha$-ketol 7 could be accessed from nitrile-containing vinylogous ester 8 using different approaches, for instance those developed by Davis, ${ }^{21-23}$ Shi, ${ }^{24}$ or Sharpless. ${ }^{25}$ Compound 8 could be produced in two steps from commercially available cyclohexane-1,3-dione using standard Stork-Danheiser $\alpha$-alkylation methodology. ${ }^{26}$

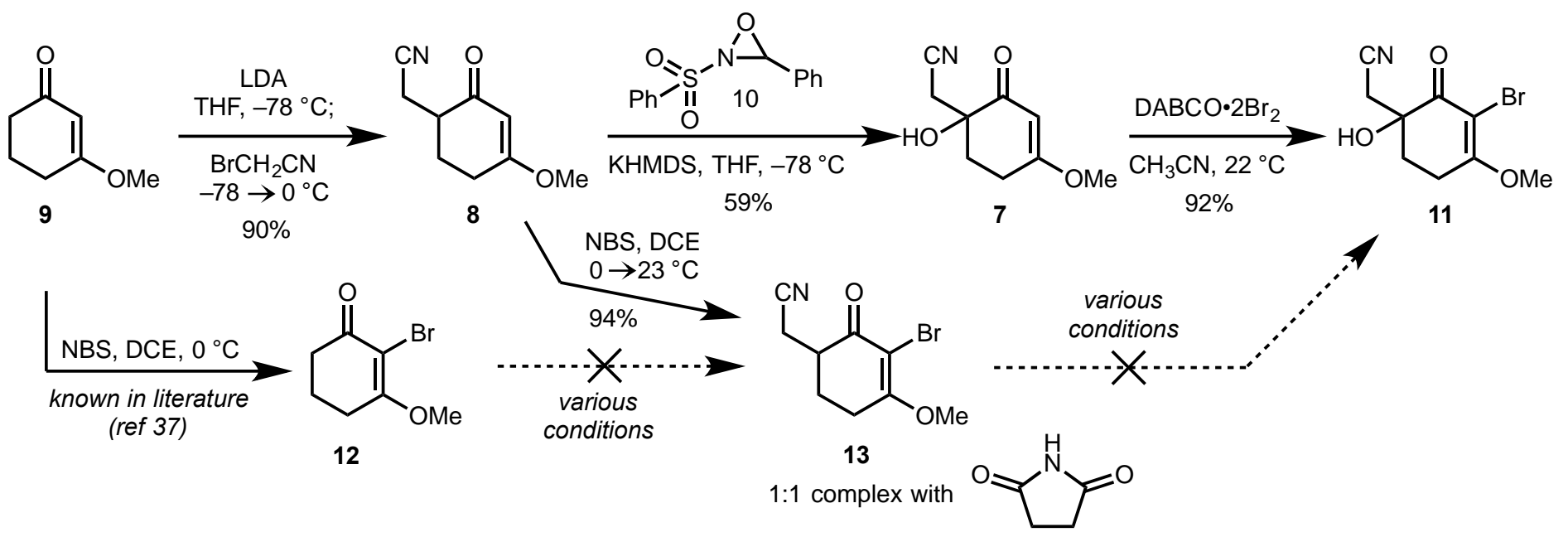

Scheme 4. Preparation of intermediates 7 and 11.

Our synthetic studies began with the preparation of $\alpha$-ketol 7 (Scheme 4). Vinylogous ester 9 (which is commercially available, but more effectively produced from cyclohexane-1,3-dione in moderate yield on up to $30 \mathrm{~g}$ scale after distillation or in essentially quantitative yield on scales up to $1 \mathrm{~g}$ with purification by column chromatography ${ }^{27}$ underwent smooth alkylation with bromoacetonitrile using freshly prepared lithium diisopropylamide (LDA) as a base, yielding the desired cyano compound (8) in very good yield. Treatment of nitrile 8 with potassium hexamethyldisilazide (KHMDS), followed by oxygenation with Davis' oxaziridine (10) ${ }^{19-}$ ${ }^{21}$ afforded the crucial $\alpha$-ketol 7 in good yield (59\% along with $10 \%$ of recovered 8). ${ }^{28,29}$ Notably, other amidetype bases proved much less efficient in this transformation.

With compound $\mathbf{7}$ in hand, we commenced exploration of the key dibromination reaction (Scheme 5). Treatment of $\mathbf{7}$ with an excess of lithium hexamethyldisilazide (LiHMDS) followed by addition of brominating reagents generated gem-dibromide $6^{30}$ in moderate yields (entries $1-5$ ). Previously we reported that $p$ toluenesulfonyl bromide ( $\mathrm{TsBr}$ ) and 1,3-dibromo-5,5-dimethylhydantoin (DBDMH) provided the best results in the preparation of similar gem-dibromo systems. ${ }^{10}$ Our attempts to utilize these reagents gave only moderate yields of desired gem-dibromide 6 , however (entries 1 \& 2). Interestingly, decreasing the bromination time (30 $\rightarrow 10 \mathrm{~min}$ ) in the reaction with DBDMH resulted in the formation of mono-bromo compound 14 in $84 \%$ isolated yield, which is presumably the precursor for gem-dibromide 6 (bromination with $\mathrm{TsBr}$ also resulted in the formation of 14). We then switched to other brominating reagents. The use of molecular bromine provided both compounds 14 and 6 in comparable yields (entry 3), whereas reaction with the bromine complex of 1,4diazabicyclo[2.2.2] octane $\left(\mathrm{DABCO} \cdot 2 \mathrm{Br}_{2}\right),{ }^{31-33}$ a reagent we have found uniquely effective for related transformations, ${ }^{14}$ showed preference for the formation of dibromide 6 , albeit in decreased yield (entry 4). Interestingly, increasing the amount of $\mathrm{DABCO} \cdot 2 \mathrm{Br}_{2}$ did not improve the yield of desired dibromide 6 , but rather changed the reaction profile favoring formation of a new compound, assigned the structure of hypobromite 15, in good yield (entry 5). ${ }^{34}$ 
Having accessed acceptable quantities of key gem-dibromide 6, we began exploring subsequent elimination to generate brominated dienone $\mathbf{1 6}$. We first tested the feasibility of our previously developed conditions (which employed LiHMDS for the elimination step) in our system. Unfortunately, addition of an extra equivalent of LiHMDS to the reaction mixture did not result in the expected elimination product (3), but rather decreased the yield of 6 (entries 6,7 ). We hypothesized that elimination may be sterically demanding due to the neopentylic nature of the $\delta$-site in bromide 6 , making LiHMDS an inappropriately bulky base. Interestingly, use of the smaller lithium diethylamide (LDEA) did not produce the desired 16 either, but, to our surprise, favored the monobromide 14 (entry 8$).^{35}$

\section{Standard conditions:}

LiHMDS (4 equiv), THF, $-10^{\circ} \mathrm{C}, 45 \mathrm{~min}$; then $\mathrm{Br}^{+}$(2.1 equiv), $-78^{\circ} \mathrm{C}, 30 \mathrm{~min}$; then base<smiles>COC1=CC(=O)C(O)(CC#N)CC1</smiles>

1. LiHMDS

2. $\mathrm{Br}^{+}$

3. Base

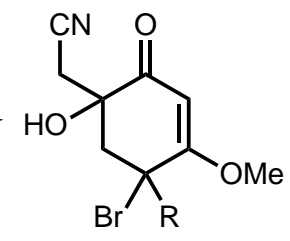

$6(\mathrm{R}=\mathrm{Br})$ $14(\mathrm{R}=\mathrm{H})$<smiles>COC1=CC(=O)C(Br)(CC#N)CC1(Br)Br</smiles>

15

(a) Shorter bromination time (10 $\mathrm{min}$ ) resulted in formation of monobromo compound 15 (84\% isolated yield).

(b) 3 equiv of $\mathrm{DABCO} \cdot 2 \mathrm{Br}_{2}$ was used; longer reaction time required $\left(1 \mathrm{~h}\right.$ at $-78^{\circ} \mathrm{C}$ then $1.5 \mathrm{~h}$ at $\left.23^{\circ} \mathrm{C}\right)$.

(c) LiHMDS (1 equiv), $30 \mathrm{~min}$ at $-78^{\circ} \mathrm{C}$.

(d) LDEA ( 2.6 equiv), $1.5 \mathrm{~h}$ at $-78^{\circ} \mathrm{C}$.

\begin{tabular}{|c|c|c|c|}
\hline Entry & $\mathrm{Br}^{+}$source & Base & Yield (6,14), $\%$ \\
\hline 1 & $\mathrm{TsBr}$ & none & 42,25 \\
\hline $2^{a}$ & $\mathrm{DBDMH}$ & none & 48,0 \\
\hline 3 & $\mathrm{Br}_{2}$ & none & 39,37 \\
\hline 4 & $\mathrm{DABCO} \cdot 2 \mathrm{Br}_{2}$ & none & 31,3 \\
\hline $5^{b}$ & $\mathrm{DABCO} \cdot 2 \mathrm{Br}_{2}$ & none & 51 (of 15) \\
\hline 6 & $\mathrm{TsBr}$ & LiHMDS $^{c}$ & 24,0 \\
\hline 7 & $\mathrm{DBDMH}$ & LiHMDS $^{c}$ & 32,0 \\
\hline 8 & $\mathrm{DABCO} \cdot 2 \mathrm{Br}_{2}$ & LDEA $^{d}$ & 11,38 \\
\hline
\end{tabular}

Scheme 5. Optimization of dibromination reaction of substrate 7.

Unable to perform the desired elimination reaction on dibromide 6 in situ, we decided to isolate this dibromide to investigate its behavior independently. Screening of different bases identified DABCO as a suitable reagent for obtaining elimination product 16 (44\% isolated yield) along with recovered substrate 6 (33\% recovery). Unfortunately, subsequent bromination at what we presumed to be the more reactive vinylic $\alpha$ carbon of dienone $\mathbf{1 6}$ with various bromination reagents only resulted in decomposition of starting material (Scheme 6). We aimed to circumvent this problem by utilizing $\mathrm{DABCO} \cdot 2 \mathrm{Br}_{2}$, a reagent we knew to be capable of $\alpha$-bromination on a similar vinylogous ester (see Scheme 4), with the DABCO serving to carry out the elimination. However, we were surprised to observe that the expected elimination did not deliver the desired compound 3 (based on comparison to NMR data collected by Waldmann and co-workers), but instead a compound of indeterminate structure (17) exhibiting deceptively simple NMR spectra. ${ }^{36}$ By our reasoning the dibromide 18, appears to satisfy the spectral criteria which suggest a single vinylic proton remains in proximity to the carbonyl, however we have been unable to obtain satisfactory HRMS data to definitively support this assignment, leaving the actual structure uncertain. Nonetheless, the inability to carry out the desired elimination to access dienone $\mathbf{3}$ proved a significant impediment to our studies. 


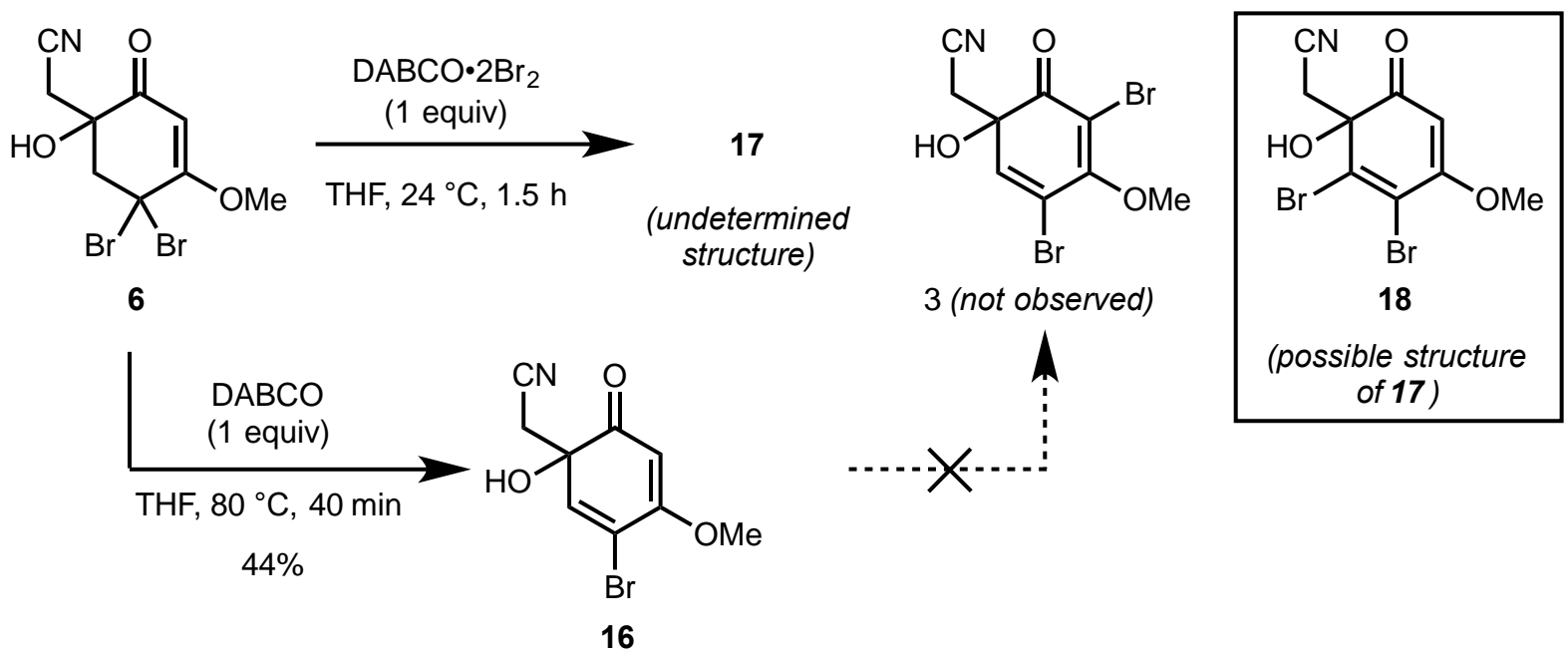

Scheme 6. Attempts to functionalize dibromide 6 and its unexpected behavior.

In an attempt to avoid this undesired behavior of halogenated compounds $\mathbf{6}$ and $\mathbf{1 6}$ during late-stage $\alpha$ bromination, we decided to modify our synthetic route and introduce an $\alpha$-bromo functionality early in the synthesis (Scheme 4). Thus, treatment of vinylogous ester 9 with $\mathrm{N}$-bromosuccinimide (NBS) allowed the generation of $\alpha$-brominated derivative $\mathbf{1 2}$ in good yield, as reported in the literature. ${ }^{37}$ Unfortunately, subsequent installation of the nitrile-containing side-chain under various reaction conditions ${ }^{38}$ did not lead to desired alkylated intermediate $\mathbf{1 3}$. However, switching the order of alkylation and bromination steps did enable formation of the desired compound (13) in excellent yield over two steps. Interestingly, organobromide $\mathbf{1 3}$ prepared in this way exists as a 1:1 complex with succinimide that cannot be broken chromatographically. This phenomenon may explain the fact that oxygenation of complex $\mathbf{1 3}$ using various protocols failed categorically (Scheme 4). To our delight, switching the reaction sequence again enabled formation of desired $\alpha$-bromo intermediate 11 in excellent yield with yet another use of $\mathrm{DABCO} \cdot 2 \mathrm{Br}_{2}$ as a brominating reagent. With intermediate 11 in hand, we applied our halogenative oxidation reaction, developed earlier, to access tribromide 19 in good yield (Scheme 7). Numerous attempts to transform tribromide 19 into dibromodienone 3, which would complete a formal synthesis of aeroplysinin, ${ }^{11}$ either yielded debrominated congener $\mathbf{2 0}$ (likely via nucleophilic attack on the halide) or produced a new compound $\mathbf{2 1}$ with an uncertain structure (see Supporting Information for details). Although a multitude of different bases have been examined, still further screening is necessary to identify the appropriate balance between basicity and nucleophilicity that will allow the desired elimination. Certainly these studies have established the extraordinary sensitivity of the aeroplysinin system to oxidative, basic, and nucleophilic conditions and entice further investigations to better understand the underlying properties that govern these unusual transformations.<smiles>COC1=C(Br)C(=O)C(O)(CC#N)CC1</smiles>

11

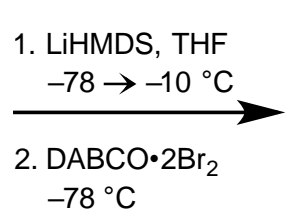

$58 \%$

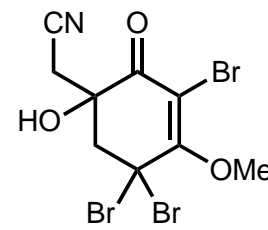

19

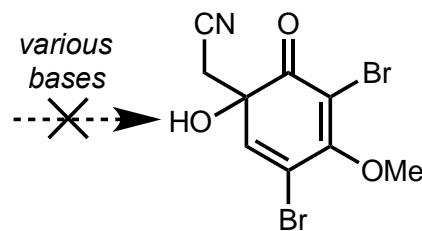

3

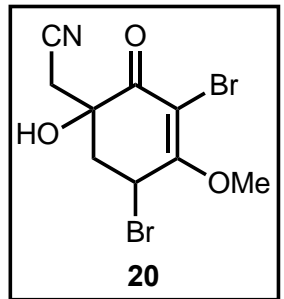

Scheme 7. Attempts to functionalize bromide 11. 


\section{Conclusions}

We have developed an efficient synthesis of a functionalized molecular framework en route to the halogenated natural product aeroplysinin (1) featuring a regiocontrolled $\gamma$-bromination of dienolate intermediates. Our optimized protocol enables access to the densely functionalized polybromide 19 in $32 \%$ yield through five synthetic steps (cyclohexane-1,3-dione $\rightarrow \mathbf{9} \rightarrow \mathbf{8} \rightarrow \mathbf{7} \rightarrow \mathbf{1 1} \rightarrow \mathbf{1 9}$ ) from commercially available starting materials. In the course of our studies we have made remarkable observations regarding the reactivity of several halogenated intermediates that inform our fundamental understanding of halogen reactivity and the properties of conjugated dienolate intermediates. Further synthetic investigations examining the feasibility of late-stage elimination reactions to access key dienone 3, a known synthetic precursor to aeroplysinin, are currently underway and will be reported in due course.

\section{Experimental Section}

General. Unless otherwise stated, reactions were performed in oven-dried glassware using dry, deoxygenated solvents. Anhydrous dichloromethane $\left(\mathrm{CH}_{2} \mathrm{Cl}_{2}\right)$, heptane, triethylamine $\left(\mathrm{Et}_{3} \mathrm{~N}\right)$, tetrahydrofuran (THF) (BHT-free) were purchased from Fisher or VWR, degassed with argon, and dried by passage through activated drying columns ${ }^{39}$ on a Pure Process Technology system. Chloroform $\left(\mathrm{CHCl}_{3}\right)$ and diethyl ether $\left(\mathrm{Et}_{2} \mathrm{O}\right)$ were purchased from either Sigma-Aldrich or Fisher Scientific and were passed through a column filled with $4 \AA$ molecular sieves (MS) prior to use. Starting materials and reagents, including cyclohexane-1,3-dione, bromoacetonitrile, $N, N^{\prime}$ dibromodimethylhydantoin (DBDMH), 1,4-diazabicyclo[2.2.2]octane (DABCO), and $\mathrm{N}$-bromosuccinimide (NBS) were purchased from Sigma-Aldrich, Alfa Aesar, Oakwood Chemical, or Fisher Scientific and used as received. Diisopropylamine was distilled from NaH immediately prior to use. KHMDS (solid) and LiHMDS (solid) were purchased from Sigma-Aldrich and stored in a glovebox and used to prepare solutions in THF by dissolving a calculated amount of solid KHMDS or LiHMDS in dry THF immediately before use. DBDMH and NBS were recrystallized from $\mathrm{H}_{2} \mathrm{O}$ prior to being used (both appear as white crystals after recrystalization). Davis' oxaziridine $(\mathbf{1 0})^{19-21}$ and $\mathrm{DABCO} \cdot 2 \mathrm{Br}_{2}{ }^{29-31}$ were prepared according to known procedures. Deuterated chloroform $\left(\mathrm{CDCl}_{3}, 99.9 \%\right.$, extra dry) was purchased from Cambridge Isotope Laboratories, Inc. and was used without further purification. Reaction temperatures were controlled by an IKAmag immersion temperature modulator. Thin-layer chromatography (TLC) was performed using Silicycle silica gel 60 F254 precoated plates $(0.25 \mathrm{~mm})$ and visualized by UV fluorescence quenching or staining with $p$-anisaldehyde or $\mathrm{KMnO}_{4}$ solutions. Flash chromatography ${ }^{40}$ was performed using either SilicycleSiliaFlash ${ }^{\circledR}$ P60 silica gel (40-63 $\mu \mathrm{m}$ particle size). ${ }^{1} \mathrm{H}$ and ${ }^{13} \mathrm{C}$ NMR spectra were recorded on a Bruker Avance DRX-500 (at 500 and $126 \mathrm{MHz}$, respectively) or DPX400 instrument (at 400 and $101 \mathrm{MHz}$, respectively) and are reported relative to $\mathrm{Me}_{4} \mathrm{Si}(\delta 0.0)$. Data for ${ }^{1} \mathrm{H} N M R$ spectra are reported as follows: chemical shift $(\delta \mathrm{ppm})$ (multiplicity, coupling constant $(\mathrm{Hz})$, integration). Multiplicities are reported as follows: $s=$ singlet, $d=$ doublet, $t=$ triplet, $q=$ quartet, sept $=$ septet, $m=$ multiplet, comp. $\mathrm{m}$ = complex multiplet, app. = apparent, br $\mathrm{s}=$ broad singlet. Data for ${ }^{13} \mathrm{C} N \mathrm{NR}$ spectra are reported in terms of chemical shift relative to $\mathrm{Me}_{4} \mathrm{Si}(\delta 0.0)$. Infrared (IR) spectra were recorded on a Nicolet iS5 FTIR spectrometer and are reported in frequency of absorption $\left(\mathrm{cm}^{-1}\right)$. High-resolution mass spectra (HRMS) were obtained from the University of Illinois at Urbana-Champaign Mass Spectral Facility. 


\section{Synthesis of compound 8}

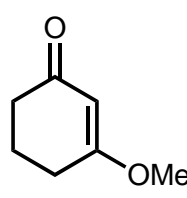

9

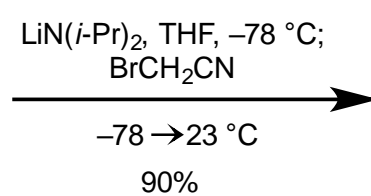

$90 \%$

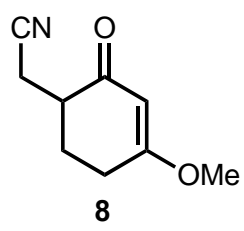

\section{Figure 1}

A $100 \mathrm{~mL}$ 2-neck round-bottom flask (equipped with a magnetic stir bar and rubber septa) was evacuated and refilled with dry $\mathrm{N}_{2}$ (3 cycles) and then was charged with freshly distilled diisopropylamine (3.6 mL, $25.28 \mathrm{mmol}$, 1.2 equiv) and dry THF $(23.3 \mathrm{~mL})$. The mixture was cooled to $0^{\circ} \mathrm{C}$ in an ice bath for $10 \mathrm{~min}$. A solution of $n$-BuLi (2.5M in hexanes, $9.4 \mathrm{~mL}, 23.44 \mathrm{mmol}, 1.1$ equiv) was then added dropwise over $2 \mathrm{~min}$ and the reaction mixture was brought to $-78{ }^{\circ} \mathrm{C}$ with a dry ice/acetone bath and allowed to stir for $10 \mathrm{~min}$. A solution of compound 8 $(2.69 \mathrm{~g}, 21.31 \mathrm{mmol}, 1$ equiv) in THF $(15.7 \mathrm{~mL})$ was then added dropwise to the reaction mixture over $5 \mathrm{~min}$ at $-78^{\circ} \mathrm{C}$ (the syringe was then rinsed with $7 \mathrm{~mL}$ of THF). After stirring for $60 \mathrm{~min}$ at $-78^{\circ} \mathrm{C}$ neat bromoacetonitrile (2.1 mL, $29.83 \mathrm{mmol}, 1.4$ equiv) was added dropwise over $5 \mathrm{~min}$ at $-78^{\circ} \mathrm{C}$. After $25 \mathrm{~min}$, TLC indicated complete consumption of starting material and reaction was quenched with deionized $\mathrm{H}_{2} \mathrm{O}(18 \mathrm{~mL})$ and diluted with EtOAc $(30 \mathrm{~mL})$ and was allowed to warm to room temperature $\left(23^{\circ} \mathrm{C}\right)$ by removing the dry ice/acetone bath. The aq phase was separated and then extracted with EtOAc ( $4 \times 20 \mathrm{~mL}$, extraction control by TLC). The combined organic phases were dried over $\mathrm{Na}_{2} \mathrm{SO}_{4}$, decanted, and concentrated in vacuo. Purification by flash chromatography $\left(\mathrm{SiO}_{2}\right.$, hexanes/EtOAc=2:1) afforded the desired product 8 as a colorless oil (3.155 g, 90\%).

$\operatorname{TLC}\left(\mathrm{SiO}_{2}\right) \mathrm{R}_{f} 0.5$ in 1:2 hexanes/EtOAc, $p$-anisaldehyde or $\mathrm{KMnO}_{4}$ stains

${ }^{1} \mathbf{H}$ NMR $\left(500 \mathrm{MHz}, \mathrm{CDCl}_{3}\right) \delta 5.41(\mathrm{~d}, J 1.5 \mathrm{~Hz}, 1 \mathrm{H}), 3.72(\mathrm{~s}, 3 \mathrm{H}), 2.96(\mathrm{dd}, J$ 16.7, $3.8 \mathrm{~Hz}, 1 \mathrm{H}), 2.67-2.39(\mathrm{~m}, 4 \mathrm{H})$, 2.38-2.28 (m, 1H), 1.87 (ddd, J 25.4, 13.0, $5.1 \mathrm{~Hz}, 1 \mathrm{H})$

${ }^{13} \mathrm{C}$ NMR $\left(126 \mathrm{MHz} \mathrm{CDCl}_{3}\right) \delta 196.0,178.4,118.6,101.4,56.0,42.0,28.6,26.6,18.1$

IR (neat) 2989, 2942, 2246, 1632, 1594, 1461, 1440, 1366, 1342, 1315, 1195, 1158, 1100, 1054, 1003, 977, 940, $891,854,815,766,688,656,586,561 \mathrm{~cm}^{-1}$

HRMS $\left(\right.$ ES $\left.^{+}\right) \mathrm{m} / z$ calculated for $\mathrm{C}_{9} \mathrm{H}_{11} \mathrm{NO}_{2}[\mathrm{M}]^{+}: 166.0868$, found 166.0860

\section{Synthesis of compound 7}

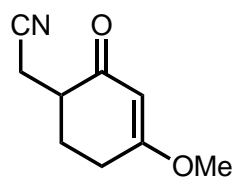

8

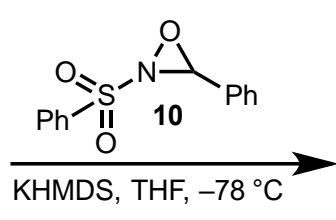

$59 \%$

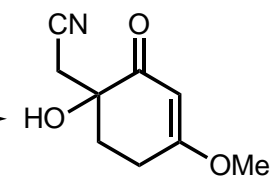

7

Figure 2

A $50 \mathrm{~mL}$ 2-neck round-bottom flask (equipped with a magnetic stir bar and rubber septa) was evacuated and refilled with dry $\mathrm{N}_{2}$ (3 cycles) and then was charged with solution of KHMDS (664 mg, $3.33 \mathrm{mmol}, 1.1$ equiv) in dry THF $(4.4 \mathrm{~mL})$. The mixture was cooled to $-78^{\circ} \mathrm{C}$ in a dry ice/acetone bath for $10 \mathrm{~min}$. A solution of compound 8 (500 mg, $3.03 \mathrm{mmol}, 1$ equiv) in THF ( $4 \mathrm{~mL}$ ) was then added dropwise over $15 \mathrm{~min}$ (the syringe was then rinsed 
with $0.7 \mathrm{~mL}$ of THF over $3 \mathrm{~min}$ ) and the reaction mixture was allowed to stir for $30 \mathrm{~min}$. A solution of compound 10 (870 mg, $3.33 \mathrm{mmol}, 1.1$ equiv) in THF $(2.5 \mathrm{~mL})$ was then added dropwise to the reaction mixture over 10 min at $-78{ }^{\circ} \mathrm{C}$ (the syringe was then rinsed with $0.4 \mathrm{~mL}$ of THF over $2 \mathrm{~min}$ ). After stirring for $50 \mathrm{~min}$ at $-78^{\circ} \mathrm{C}$ a second portion of compound 10 (712 mg, $2.72 \mathrm{mmol}, 0.9$ equiv) in THF (2.4 mL) was added to the reaction mixture. After $60 \mathrm{~min}, \mathrm{TLC}$ indicated complete consumption of starting material and the reaction was quenched with saturated aq $\mathrm{NH}_{4} \mathrm{Cl}$ soln $(30 \mathrm{~mL})$ and diluted with EtOAc $(20 \mathrm{~mL})$ and the mixture was allowed to warm to room temperature $\left(23^{\circ} \mathrm{C}\right)$ by removing the dry ice/acetone bath. The aq phase was separated and then extracted with EtOAc $(5 \times 10 \mathrm{~mL}$, extraction control by TLC). The combined organic phases were dried over $\mathrm{Na}_{2} \mathrm{SO}_{4}$, decanted, and concentrated in vacuo. Purification by flash chromatography $\left(\mathrm{SiO}_{2}\right.$, hexanes/EtOAc=1:1) afforded the desired product 7 as a yellowish oil (318 g, 59\%) and recovered starting material 8 (50 mg, 10\%). $\operatorname{TLC}\left(\mathrm{SiO}_{2}\right) \mathrm{R}_{f} 0.36$ in 1:2 hexanes/EtOAc, $p$-anisaldehyde or $\mathrm{KMnO}_{4}$ stains

${ }^{1} \mathrm{H}$ NMR $\left(500 \mathrm{MHz} \mathrm{CDCl}_{3}\right) \delta 5.42(\mathrm{~s}, 1 \mathrm{H}), 4.04(\mathrm{~s}, 1 \mathrm{H}), 3.76(\mathrm{~s}, 3 \mathrm{H}), 2.67(\mathrm{~d}, J 16.8 \mathrm{~Hz}, 1 \mathrm{H}), 2.61(\mathrm{~d}, J 16.8 \mathrm{~Hz}, 1 \mathrm{H})$, 2.65-2.49 (m, 2H), 2.39 (ddd, J 13.9, 5.2, 3.2 Hz, 1H), 2.13 (ddd, J 13.8, 11.2, $6.2 \mathrm{~Hz}, 1 \mathrm{H}$ )

${ }^{13} \mathrm{C}$ NMR $\left(126 \mathrm{MHz}, \mathrm{CDCl}_{3}\right) \delta 196.9,178.8,116.0,98.4,71.4,56.5,31.4,27.2,26.9$

IR (neat) 3381 (broad), 2923, 2251, 1640, 1588, 1437, 1416, 1381, 1352, 1321, 1302, 1251, 1199, 1113, 1072, 1015, 974, 935, 904, 880, 837, 799, 760, 739, 720, 702, $593 \mathrm{~cm}^{-1}$

HRMS $\left(\mathrm{ES}^{+}\right) \mathrm{m} / \mathrm{z}$ calculated for $\mathrm{C}_{9} \mathrm{H}_{11} \mathrm{NO}_{3}[\mathrm{M}]^{+}:$: 182.0817, found 182.0814

\section{Synthesis of compound 6}
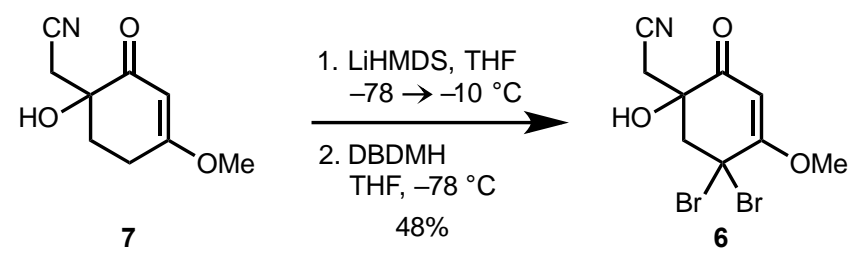

\section{Figure 3}

A $20 \mathrm{~mL}$ glass scintillation vial (equipped with a magnetic stir bar and rubber septum) was evacuated and refilled with dry $\mathrm{N}_{2}$ ( 3 cycles) and then was charged with a solution of compound 7 ( $82 \mathrm{mg}, 0.45 \mathrm{mmol}, 1$ equiv) in THF $(2.3 \mathrm{~mL})$ and the reaction mixture was cooled to $-78^{\circ} \mathrm{C}$ in a dry ice/acetone bath for $5 \mathrm{~min}$. A solution of LiHMDS ( $1 \mathrm{M}$ in THF, $1.81 \mathrm{~mL}, 1.81 \mathrm{mmol}, 4$ equiv) was then added at once and the reaction mixture was allowed to stir for $5 \mathrm{~min}$ at $-78{ }^{\circ} \mathrm{C}$. The reaction temperature was then increased to $-20^{\circ} \mathrm{C}$ by replacing the dry ice/acetone bath with an ice $/ \mathrm{NaCl}$ bath and the reaction was allowed to stir for $20 \mathrm{~min}$ at this temperature. The reaction mixture was then cooled back to $-78{ }^{\circ} \mathrm{C}$ for $5 \mathrm{~min}$ and a solution of DBDMH ( $272 \mathrm{mg}, 0.95 \mathrm{mmol}, 2.1$ equiv) in THF $(1.2 \mathrm{~mL})$ was added dropwise over $2 \mathrm{~min}$. After stirring for $40 \mathrm{~min}$ at $-78{ }^{\circ} \mathrm{C}$ TLC indicated complete consumption of starting material and complete conversion of the monobromo intermediate into compound 6. The reaction was quenched with deionized $\mathrm{H}_{2} \mathrm{O}(3 \mathrm{~mL})$ and diluted with EtOAc $(3 \mathrm{~mL})$ and was allowed to warm to room temperature $\left(23^{\circ} \mathrm{C}\right)$ by removing the dry ice/acetone bath. The aq phase was separated and then extracted with EtOAc ( $6 \times 3 \mathrm{~mL}$, extraction control by TLC). The combined organic phases were dried over $\mathrm{Na}_{2} \mathrm{SO}_{4}$, decanted, and concentrated in vacuo. Purification by flash chromatography $\left(\mathrm{SiO}_{2}\right.$, hexanes/EtOAc=1:1) afforded the desired compound 6 as an orange oil ( $85 \mathrm{mg}, 48 \%$ ).

TLC $\left(\mathrm{SiO}_{2}\right) \mathrm{R}_{f} 0.64$ in 1:2 hexanes/EtOAc, $p$-anisaldehyde or $\mathrm{KMnO}_{4}$ stains 
${ }^{1} \mathrm{H}$ NMR (500 MHz, CDCl $) \delta 5.38(\mathrm{~s}, 1 \mathrm{H}), 3.97(\mathrm{~s}, 1 \mathrm{H}), 3.96(\mathrm{~s}, 3 \mathrm{H}), 3.72(\mathrm{~d}, J 15.9 \mathrm{~Hz}, 1 \mathrm{H}), 3.46(\mathrm{~d}, J 15.9 \mathrm{~Hz}, 1 \mathrm{H})$, $3.00(\mathrm{~d}, J 16.8 \mathrm{~Hz}, 1 \mathrm{H}), 2.78(\mathrm{~d}, J 16.8 \mathrm{~Hz}, 1 \mathrm{H})$

${ }^{13} \mathrm{C}$ NMR $\left(126 \mathrm{MHz}, \mathrm{CDCl}_{3}\right) \delta$ 194.6, 171.5, 115.3, 96.1, 71.7, 57.9, 53.6, 48.1, 28.2

IR (neat) 3415 (broad), 2924, 2850, 2254, 1666, 1595, 1455, 1438, 1347, 1213, 1093, 1058, 971, 854, 732, 710, $633,582,557 \mathrm{~cm}^{-1}$

HRMS $\left(\right.$ ES $\left.^{+}\right) \mathrm{m} / \mathrm{z}$ calculated for $\mathrm{C}_{9} \mathrm{H}_{9} \mathrm{Br}_{2} \mathrm{NO}_{3}[\mathrm{M}]^{+}: 337.9027$, found 337.9031

\section{Synthesis of compound 15}

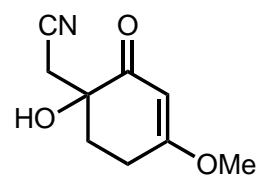

7

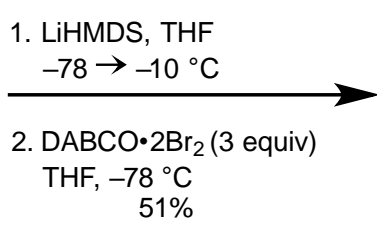

$51 \%$

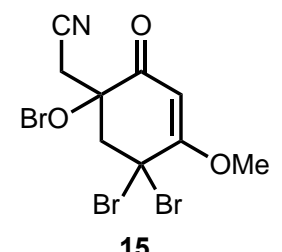

15

\section{Figure 4}

A $4 \mathrm{~mL}$ glass scintillation vial (equipped with a magnetic stir bar and rubber septum) was evacuated and refilled with dry $\mathrm{N}_{2}$ ( 3 cycles) and then was charged with a solution of compound 7 ( $30 \mathrm{mg}, 0.17 \mathrm{mmol}, 1$ equiv) in THF $(0.8 \mathrm{~mL})$ and the reaction mixture was cooled to $-78{ }^{\circ} \mathrm{C}$ in dry ice/acetone bath for $5 \mathrm{~min}$. A solution of LiHMDS (1M in THF, $0.63 \mathrm{~mL}, 0.63 \mathrm{mmol}, 4$ equiv) was then added at once and the reaction mixture was allowed to stir for $5 \mathrm{~min}$ at $-78{ }^{\circ} \mathrm{C}$. The reaction temperature was increased to $-20^{\circ} \mathrm{C}$ by replacing the dry ice/acetone bath with an ice/ $\mathrm{NaCl}$ bath and the reaction was allowed to stir for $20 \mathrm{~min}$ at this temperature. The reaction mixture was then cooled back to $-78{ }^{\circ} \mathrm{C}$ for $5 \mathrm{~min}$ and solid $\mathrm{DABCO} \cdot 2 \mathrm{Br}_{2}(85.8 \mathrm{mg}, 0.5 \mathrm{mmol}, 3$ equiv) was then added in one portion through a powder funnel with a backflow of $\mathrm{N}_{2}$. The reaction was allowed to stir at $-78^{\circ} \mathrm{C}$ for $1 \mathrm{~h}$ and then the reaction temperature was increased to $23^{\circ} \mathrm{C}$ by removing the dry ice/acetone bath. After $30 \mathrm{~min}$ at $23{ }^{\circ} \mathrm{C}$, TLC indicated complete consumption of starting material and complete conversion of the monobromo intermediate into compound 15 . The reaction was quenched with saturated aq $\mathrm{NH}_{4} \mathrm{Cl}$ soln $(0.3 \mathrm{~mL})$ and diluted with EtOAc $(1 \mathrm{~mL})$ and deionized $\mathrm{H}_{2} \mathrm{O}(1 \mathrm{~mL})$. The aq phase was separated and then extracted with EtOAc $(4 \times 3$ $\mathrm{mL}$, extraction control by $\mathrm{TLC}$ ). The combined organic phases were dried over $\mathrm{Na}_{2} \mathrm{SO}_{4}$, decanted, and concentrated in vacuo. Purification by flash chromatography $\left(\mathrm{SiO}_{2}\right.$, hexanes/EtOAc=4:1) afforded the desired compound 15 as an orange oil (34.5 $\mathrm{mg}, 51 \%)$.

$\mathrm{TLC}\left(\mathrm{SiO}_{2}\right) \mathrm{R}_{f} 0.86$ in 1:2 hexanes/EtOAc, $p$-anisaldehyde or $\mathrm{KMnO}_{4}$ stains

${ }^{1} \mathbf{H}$ NMR $\left(500 \mathrm{MHz}, \mathrm{CDCl}_{3}\right) \delta 5.29(\mathrm{~s}, 1 \mathrm{H}), 3.93(\mathrm{~s}, 3 \mathrm{H}), 3.59(\mathrm{~d}, J 15.5 \mathrm{~Hz}, 1 \mathrm{H}), 3.40(\mathrm{~d}, J 15.5 \mathrm{~Hz}, 1 \mathrm{H}), 2.89(\mathrm{~d}, J$ $16.9 \mathrm{~Hz}, 1 \mathrm{H}), 2.72(\mathrm{~d}, J 16.8 \mathrm{~Hz}, 1 \mathrm{H})$

${ }^{13} \mathrm{C}$ NMR $\left(126 \mathrm{MHz}_{1} \mathrm{CDCl}_{3}\right){ }^{41} \delta 192.8,171.1,115.9,97.8,74.4,57.5,54.9,48.1,31.9,29.7,29.4,27.4,22.7,14.1$, $1.4,1.0$

IR (neat) 2943, 2255, 1666, 1599, 1461, 1440, 1419, 1348, 1249, 1218, 1114, 990, 977, 943, 888, 840, 781, 755, $699,651,635,592 \mathrm{~cm}^{-1}$

LRMS (m/z): 422.8, 421.8, 420.8, 419.8, 418.8, 417.8 (100\%), 416.8, 415.8. Attempts to obtain HRMS for this compound were unsuccessful. 


\section{Synthesis of compound 16}

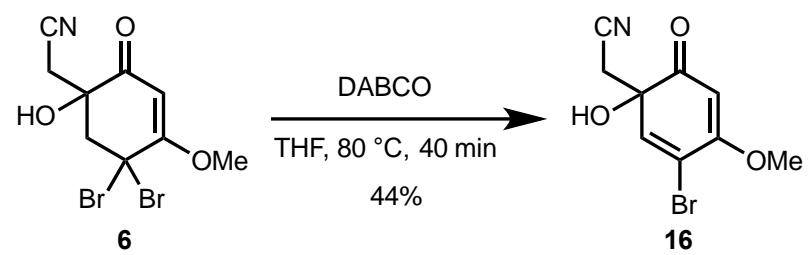

\section{Figure 5}

A $4 \mathrm{~mL}$ glass scintillation vial (equipped with a magnetic stir bar) was charged with a solution of compound 6 (34 $\mathrm{mg}, 0.1 \mathrm{mmol}, 1$ equiv) in THF ( $0.4 \mathrm{~mL})$ and DABCO (22.4 mg, $0.2 \mathrm{mmol}, 2$ equiv). The vial was then sealed with a cap and placed in an aluminum block preheated to $80^{\circ} \mathrm{C}$. The reaction was stirred for $1.5 \mathrm{~h}$ at which time TLC indicated consumption of starting material. The mixture was cooled to $22{ }^{\circ} \mathrm{C}$ and then treated with saturated aq $\mathrm{NH}_{4} \mathrm{Cl}$ soln $(1 \mathrm{~mL})$ and diluted with EtOAc $(1 \mathrm{~mL})$. The aq phase was separated and then extracted with EtOAc $\left(3 \times 1 \mathrm{~mL}\right.$, extraction control by TLC). The combined organic phases were dried over $\mathrm{Na}_{2} \mathrm{SO}_{4}$, decanted, and concentrated in vacuo. Purification by flash chromatography $\left(\mathrm{SiO}_{2}\right.$, hexanes/EtOAc=2.2:1) afforded the desired compound 16 as a colorless oil (11.4 mg, 44\%).

$\operatorname{TLC}\left(\mathrm{SiO}_{2}\right) \mathrm{R}_{f} 0.33$ in 1:1 hexanes/EtOAc, $p$-anisaldehyde or $\mathrm{KMnO}_{4}$ stains

${ }^{1} \mathrm{H}$ NMR $\left(500 \mathrm{MHz} \mathrm{CDCl}_{3}\right) \delta 7.00(\mathrm{~s}, 1 \mathrm{H}), 5.60(\mathrm{~s}, 1 \mathrm{H}), 3.92(\mathrm{~s}, 3 \mathrm{H}), 3.69(\mathrm{~s}, 1 \mathrm{H}), 2.72(\mathrm{~d}, J 16.4 \mathrm{~Hz}, 1 \mathrm{H}), 2.66(\mathrm{~d}, J$ $16.4 \mathrm{~Hz}, 1 \mathrm{H})$

${ }^{13} \mathrm{C}$ NMR $\left(126 \mathrm{MHz}, \mathrm{CDCl}_{3}\right) \delta 197.5,166.9,140.8,117.6,114.6,98.1,74.2,57.7,30.6$

IR (neat) 3368 (broad), 2922, 2851, 2253, 1741, 1650, 1566, 1455, 1411, 1367, 1213, 1101, 999, 967, 826, 781, $730,626,601 \mathrm{~cm}^{-1}$

HRMS $\left(\right.$ ES $\left.^{+}\right) \mathrm{m} / z$ calculated for $\mathrm{C}_{9} \mathrm{H}_{8} \mathrm{BrNO}_{3}[\mathrm{M}]^{+}:$: 257.9766, found 257.9757

\section{Attempted tandem bromination/elimination with compound 6}

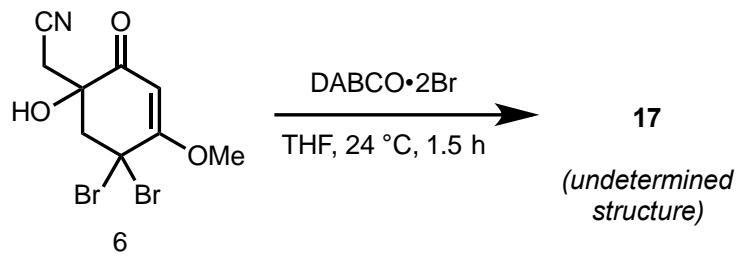

\section{Figure 6}

A $4 \mathrm{~mL}$ glass scintillation vial (equipped with a magnetic stir bar) was charged with a solution of compound 6 ( $8.9 \mathrm{mg}, 0.026 \mathrm{mmol}, 1$ equiv) in THF $(0.13 \mathrm{~mL})$ and $\mathrm{DABCO} \cdot 2 \mathrm{Br}_{2}(11.4 \mathrm{mg}, 0.026 \mathrm{mmol}, 1$ equiv). The reaction was stirred at $24^{\circ} \mathrm{C}$ for $1.5 \mathrm{~h}$ at which time TLC indicated consumption of starting material. The reaction mixture was then treated with saturated aq $\mathrm{NH}_{4} \mathrm{Cl}$ soln $(1 \mathrm{~mL})$ and diluted with EtOAc $(1 \mathrm{~mL})$. The aq phase was separated and then extracted with EtOAc $(3 \times 1 \mathrm{~mL}$, extraction control by TLC). The combined organic phases were dried over $\mathrm{Na}_{2} \mathrm{SO}_{4}$, decanted, and concentrated in vacuo. Purification by flash chromatography $\left(\mathrm{SiO}_{2}\right.$, hexanes/EtOAc=2:1) afforded 17 as a colorless oil (2.5 mg). 
TLC $\left(\mathrm{SiO}_{2}\right) \mathrm{R}_{f} 0.36$ in 1:1 hexanes/EtOAc, $p$-anisaldehyde or $\mathrm{KMnO}_{4}$ stains

${ }^{1} \mathrm{H}$ NMR $\left(500 \mathrm{MHz}, \mathrm{CDCl}_{3}\right) \delta 5.86(\mathrm{~s}, 1 \mathrm{H}), 4.08(\mathrm{~s}, 1 \mathrm{H}), 3.83(\mathrm{~s}, 3 \mathrm{H}), 3.29(\mathrm{~d}, J 17.8 \mathrm{~Hz}, 1 \mathrm{H}), 3.20(\mathrm{~d}, J 17.8 \mathrm{~Hz}, 1 \mathrm{H})$

${ }^{13} \mathrm{C}$ NMR $\left(126 \mathrm{MHz}, \mathrm{CDCl}_{3}\right) \delta 188.6,185.2,159.8,113.8,107.2,58.0,56.9,56.5,17.9$

IR (neat) 3356 (broad), 3189, 3067, 2921, 2850, 2359, 2259, 1701, 1683, 1615, 1459, 1440, 1410, 1298, 1267, $1244,1220,1198,1173,1107,1067,1019,983,961,940,873,842,789,749,698,643,602 \mathrm{~cm}^{-1}$

HRMS (ES ${ }^{+}$, selected peaks) m/z: 437.1944 (23\%), 413.2123 (22\%), 357.5771 (8\%), 316.3211 (22\%) 288.2907 (43\%), 282.2807 (100\%), 256.2648 (23\%)

\section{Synthesis of compound 13}

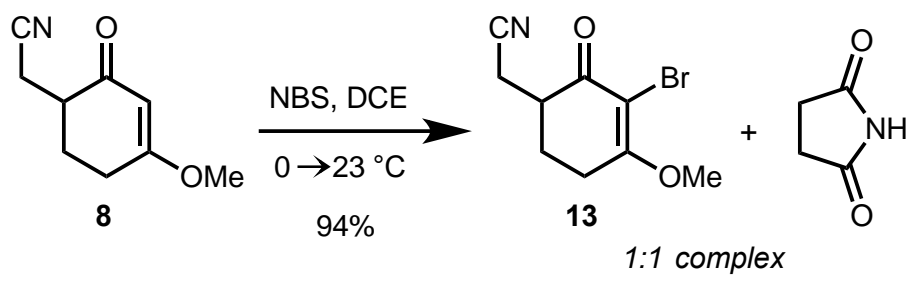

\section{Figure 7}

A $20 \mathrm{~mL}$ glass scintillation vial (equipped with a magnetic stir bar) was charged with compound 8 (200 mg, 1.21 mmol, 1 equiv) and 1,2-dichloroethane (DCE, $1.1 \mathrm{~mL}$ ). The mixture was cooled to $0{ }^{\circ} \mathrm{C}$ in an ice bath for $10 \mathrm{~min}$ and then NBS (334 mg, $1.87 \mathrm{mmol}, 1.55$ equiv) was added portionwise over $10 \mathrm{~min}$. The reaction mixture was allowed to warm up to $23{ }^{\circ} \mathrm{C}$ over a period of $2.5 \mathrm{~h}$, after which TLC indicated consumption of starting material. The reaction mixture was then filtered, and the filtrate was concentrated in vacuo. Purification by flash chromatography ( $\mathrm{SiO}_{2}$, hexanes/EtOAc=1:1) afforded a 1:1 complex of 13 with succinimide (387 mg, 94\%).

TLC $\left(\mathrm{SiO}_{2}\right) \mathrm{R}_{f} 0.26$ in 1:2 hexanes/EtOAc, $p$-anisaldehyde or $\mathrm{KMnO}_{4}$ stains

${ }^{1} \mathbf{H}$ NMR $\left(500 \mathrm{MHz}, \mathrm{CDCl}_{3}\right) \delta 8.69(\mathrm{~s}, 1 \mathrm{H}), 3.98(\mathrm{~s}, 3 \mathrm{H}), 3.02$ (dd, J 17.1, 4.2 Hz, 1H), 2.91 (ddd, J 17.8, 5.0, 2.6 Hz, $1 \mathrm{H}), 2.79-2.64(\mathrm{~m}, 2 \mathrm{H}), 2.74(\mathrm{~s}, 4 \mathrm{H}), 2.51(\mathrm{dd}, J 17.1,9.0 \mathrm{~Hz}, 1 \mathrm{H}), 2.46-2.39(\mathrm{~m}, 1 \mathrm{H}), 1.90$ (ddd, J 25.2, $13.4,5.1$ $\mathrm{Hz}, 1 \mathrm{H})$

${ }^{13} \mathrm{C}$ NMR $\left(126 \mathrm{MHz}, \mathrm{CDCl}_{3}\right) \delta 188.7,177.8,173.1,118.2,101.6,56.6,42.1,29.6,26.3,25.5,18.6$

IR (neat) 3143 (broad), 3078 (broad), 2953, 2919, 2850, 2249, 1771, 1693, 1634, 1564, 1460, 1419, 1402, 1355, $1287,1271,1230,1174,1102,1066,1049,1020,1004,935,914,894,849,805,721,652,578,556 \mathrm{~cm}^{-1}$

HRMS $\left(\mathrm{ES}^{+}\right) \mathrm{m} / \mathrm{z}$ calculated for $\mathrm{C}_{9} \mathrm{H}_{10} \mathrm{BrNO}_{2}[\mathrm{M}]^{+}:$243.9973, found 243.9982

\section{Synthesis of compound 21}
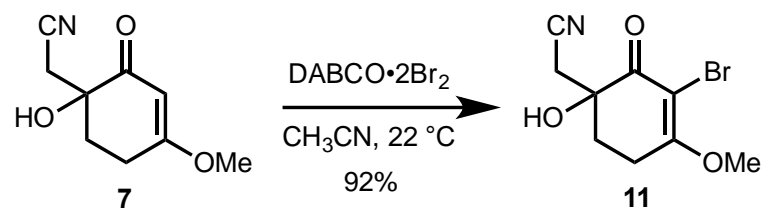

Figure 8

A $20 \mathrm{~mL}$ glass scintillation vial (equipped with a magnetic stir bar) was charged with compound 7 (269 $\mathrm{mg}, 1.49$ mmol, 1 equiv), $\mathrm{CH}_{3} \mathrm{CN}\left(4.95 \mathrm{~mL}\right.$ ), and $\mathrm{DABCO} \bullet 2 \mathrm{Br}_{2}$ (385 mg, $0.891 \mathrm{mmol}, 0.6$ equiv). After stirring for $30 \mathrm{~min}$ at 
$22{ }^{\circ} \mathrm{C}$, TLC indicated complete consumption of starting material. The reaction mixture was diluted with $\mathrm{CH}_{2} \mathrm{Cl}_{2}$ $(6 \mathrm{~mL})$, filtered through a Celite pad, and concentrated in vacuo, yielding the desired compound 11 as yellowish oil (354 mg, 92\%).

$\operatorname{TLC}\left(\mathrm{SiO}_{2}\right) \mathrm{R}_{f} 0.35$ in 1:2 hexanes/EtOAc, $p$-anisaldehyde or $\mathrm{KMnO}_{4}$ stains

${ }^{1} \mathrm{H}$ NMR $\left(500 \mathrm{MHz}, \mathrm{CDCl}_{3}\right) \delta 4.04(\mathrm{~s}, 3 \mathrm{H}), 3.82(\mathrm{~s}, 1 \mathrm{H}), 2.97$ (ddd, J 18.5, 5.7, 3.7 Hz, 1H), 2.72 (ddd, J 18.5, 10.3, $5.4 \mathrm{~Hz}, 1 \mathrm{H}$ ), 2.67 (d, J $2.3 \mathrm{~Hz}, 2 \mathrm{H}$ ), 2.52 (ddd, J 14.1, 5.2, 3.7 Hz, 1H), 2.24 (ddd, J 14.3, 10.2, $5.8 \mathrm{~Hz}, 1 \mathrm{H}$ )

${ }^{13} \mathrm{C}$ NMR $\left(126 \mathrm{MHz} \mathrm{CDCl}_{3}\right) \delta 190.4,173.7,115.6,98.3,71.9,56.9,30.4,27.3,24.5$

IR (neat) 3409 (broad), 2922, 2852, 2256, 1652, 1561, 1459, 1409, 1268, 1225, 1172, 1108, 1030, 959, 944, 910, $797,732,715,679,649,625,566 \mathrm{~cm}^{-1}$

HRMS $\left(\mathrm{ES}^{+}\right) \mathrm{m} / \mathrm{z}$ calculated for $\mathrm{C}_{9} \mathrm{H}_{10} \mathrm{BrNO}_{3}[\mathrm{M}]^{+}:$259.9922, found 259.9931

\section{Synthesis of compound 19}

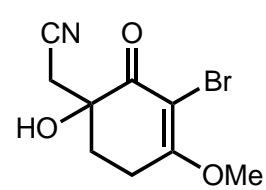

11

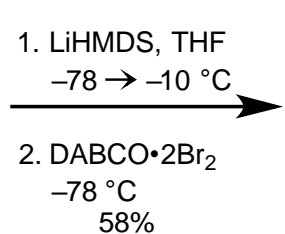

$58 \%$

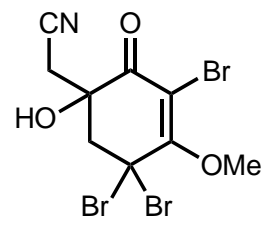

19

\section{Figure 9}

A $20 \mathrm{~mL}$ glass scintillation vial (equipped with a magnetic stir bar and a rubber septum) was evacuated and refilled with dry $\mathrm{N}_{2}$ (3 cycles) and then was charged with a solution of compound 11 (78 $\mathrm{mg}, 0.3 \mathrm{mmol}, 1$ equiv) in THF $(1.5 \mathrm{~mL})$ and the reaction mixture was cooled to $-78^{\circ} \mathrm{C}$ in a dry ice/acetone bath for $5 \mathrm{~min}$. A solution of LiHMDS (1 M in THF, $1.81 \mathrm{~mL}, 1.81 \mathrm{mmol}, 4$ equiv) was then added at once and the reaction mixture was allowed to stir for $5 \mathrm{~min}$ at $-78^{\circ} \mathrm{C}$. The reaction temperature was increased to $-20^{\circ} \mathrm{C}$ by replacing the dry ice/acetone bath with an ice/ $\mathrm{NaCl}$ bath and the reaction was allowed to stir for $20 \mathrm{~min}$ at this temperature. The reaction mixture was then cooled back to $-78{ }^{\circ} \mathrm{C}$ for $5 \mathrm{~min}$ and solid $\mathrm{DABCO} \cdot 2 \mathrm{Br}_{2}(259 \mathrm{mg}, 0.6 \mathrm{mmol}, 2$ equiv) was added at once through a powder funnel with a backflow of $\mathrm{N}_{2}$. The reaction was allowed to stir at $-78{ }^{\circ} \mathrm{C}$ for $1.75 \mathrm{~h}$ and then the reaction temperature was increased to $0{ }^{\circ} \mathrm{C}$ by replacing the dry ice/acetone bath with an ice bath. After $30 \mathrm{~min}$ at $0^{\circ} \mathrm{C}$, TLC indicated complete consumption of starting material and complete conversion of monobromo intermediate into compound 19. The reaction was quenched with saturated aq $\mathrm{NH}_{4} \mathrm{Cl}$ soln $(1 \mathrm{~mL})$ and diluted with EtOAc $(5 \mathrm{~mL})$ and deionized $\mathrm{H}_{2} \mathrm{O}(5 \mathrm{~mL})$. The aq phase was separated and then extracted with EtOAc ( $3 \times 5 \mathrm{~mL}$, extraction control by TLC). The combined organic phases were dried over $\mathrm{Na}_{2} \mathrm{SO}_{4}$, decanted, and concentrated in vacuo. Purification by flash chromatography $\left(\mathrm{SiO}_{2}\right.$, hexanes/EtOAc=1:2) afforded the desired compound 19 as orange oil (73 $\mathrm{mg}, 58 \%$ ).

$\operatorname{TLC}\left(\mathrm{SiO}_{2}\right) \mathrm{R}_{f}=0.78$ in 1:2 hexanes/EtOAc, $p$-anisaldehyde or $\mathrm{KMnO}_{4}$ stains

${ }^{1} \mathbf{H}$ NMR $\left(500 \mathrm{MHz}, \mathrm{CDCl}_{3}\right) \delta 4.39(\mathrm{~s}, 3 \mathrm{H}), 3.89(\mathrm{~s}, 1 \mathrm{H}), 3.73(\mathrm{~d}, J 16.0 \mathrm{~Hz}, 1 \mathrm{H}), 3.49(\mathrm{~d}, J 16.0 \mathrm{~Hz}, 1 \mathrm{H}), 2.99(\mathrm{~d}, J$ $16.8 \mathrm{~Hz}, 1 \mathrm{H}), 2.81(\mathrm{~d}, J 16.8 \mathrm{~Hz}, 1 \mathrm{H})$

${ }^{13} \mathrm{C}$ NMR $\left(126 \mathrm{MHz} \mathrm{CDCl}_{3}\right) \delta 189.8,168.6,114.7,103.8,72.3,64.7,52.3,50.5,28.4$

IR (neat) 3360 (broad), 2928, 2849, 2266, 1689, 1562, 1455, 1431, 1409, 1352, 1259, 1206, 1168, 1069, 933, $853,822,764,720,691,631,605 \mathrm{~cm}^{-1}$

HRMS $\left(\right.$ ES $\left.^{+}\right) \mathrm{m} / \mathrm{z}$ calculated for $\mathrm{C}_{9} \mathrm{H}_{8} \mathrm{Br}_{3} \mathrm{NO}_{3}[\mathrm{M}]^{+}:$: 415.8133, found 415.8131 


\section{Acknowledgements}

Funding was provided through start-up funds from the UIC Department of Chemistry and through the National Science Foundation (CAREER Award 1654490). We thank Prof. Duncan Wardrop, Prof. Daesung Lee, and Prof. Vladimir Gevorgyan (UIC) for helpful discussions. We also thank Prof. Dr. H. Waldmann (Max Planck Institute-Dortmund) for providing spectroscopic data for compound 3.

\section{Supplementary Data}

The ${ }^{1} \mathrm{H}$ NMR and ${ }^{13} \mathrm{C}$ NMR data associated with this article can be found in the online version.

\section{References and Notes}

1. Gribble, G. W. Acc. Chem. Res. 1998, 31, 141-152.

https://doi.org/10.1021/ar9701777

2. Gribble, G.W. In Progress in the Chemistry of Organic Natural Products, 2010, 91, 1-613.

3. Fattorusso, E; Minale, L.; Sodano, G. J. Chem. Soc. D 1970, 751-752.

https://doi.org/10.1039/c29700000751

4. Fuimor, W.; Van Lear, G. E.; Morton, G. O.; Mills, R. D. Tetrahedron Lett. 1970, 11, 4551-4552. https://doi.org/10.1016/S0040-4039(00)89414-9

5. Teeyapant R., Proksch P. Naturwissenschaften 1993, 80, 369-370. https://doi.org/10.1007/BF01138794

6. Fattorusso, E.; Minale, L.; Sodano, G. J. Chem. Soc., Perkin Trans. 1 1972, 16-18. https://doi.org/10.1039/p19720000016

7. Teeyapant, R.; Woerdenbag, H. J.; Kreis, P.; Hacker, J.; Wray, V.; Witte, L.; Proksch, P. Z. Naturforsch. C. 1993, 48, 939-945.

8. Martinez-Poveda, B.; Rodriguez-Nieto, S.; Garcia-Caballero, M.; Medina, M. A.; Quesada, A. R. Mar. Drugs 2012, 10, 2033-2046.

https://doi.org/10.3390/md10092033

9. Martınez-Poveda, B.; Garcıa-Vilas, J. A.; Cardenas, C.; Melgarejo, E.; Quesada, A. R.; Medina, M. A. PLoS One 2013, 8, e55203.

https://doi.org/10.1371/journal.pone.0055203

10. Andersen, R. J.; Faulkner, D. J. J. Am. Chem. Soc. 1975, 97, 936-937. https://doi.org/10.1021/ja00837a065

11. Hinterding, K.; Knebel, A.; Herrlich, P.; Waldmann, H. Bioorg. Med. Chem. 1998, 6, 1153-1162. https://doi.org/10.1016/S0968-0896(98)00070-4

12. Ogamino, T.; Nishiyama, S. Tetrahedron 2003, 59, 9419-9423. https://doi.org/10.1016/i.tet.2003.09.075

13. Ogamino, T.; Obata, R.; Nishiyama, S. Tetrahedron Lett. 2006, 47, 727-731. https://doi.org/10.1016/j.tetlet.2005.11.097

14. Chen, X.; Martinez, J. S.; Mohr, J. T. Org. Lett. 2015, 17, 378-381. https://doi.org/10.1021/ol503561x 
15. Chen, X.; Liu, X.; Martinez, J. S.; Mohr, J. T. Tetrahedron 2016, 72, 3653-3665. https://doi.org/10.1016/j.tet.2016.02.006

16. Grabovyi, G. A.; Mohr, J. T. Org. Lett. 2016, 18, 5010-5013. https://doi.org/10.1021/acs.orglett.6b02469

17. Chen, X.; Liu, X.; Mohr, J. T. Org. Lett. 2016, 18, 716-719. https://doi.org/10.1021/acs.orglett.5b03689

18. Zhao, M.; Mohr, J. T. Tetrahedron 2017, 73, 4115-4124. https://doi.org/10.1016/j.tet.2016.12.055

19. Deng, Y.; Kauser, N. I.; Islam, S. M.; Mohr, J. T. Eur. J. Org. Chem. 2017, 5872-5879. https://doi.org/10.1002/ejoc.201700899

20. Das, P.; Valente, E. J.; Hamme II, A. T. Eur. J. Org. Chem. 2014, 2659-2663. https://doi.org/10.1002/ejoc.201400009

21. Davis, F. A.; Lamendola, J., Jr.; Nadir, U.; Kluger, E. W.; Sedergran, T. C.; Panunto, T. W.; Billmers, R.; Jenkins, R., Jr.; Turci, I. J.; Watson, W. H.; Chen, J. S.; Kimura, M. J. Am. Chem. Soc. 1980, 102, 2000-2005. https://doi.org/10.1021/ja00526a040

22. Vishwakarma, L. C.; Stringer, O. D.; Davis, F. A. Org. Synth. 1988, 66, 203-210. https://doi.org/10.15227/orgsyn.066.0203

23. Davis, F. A.; Chattopadhyay, S.; Towson, J. C.; Lal, S.; Reddy, T. J. Org. Chem. 1988, 53, 2087-2089. https://doi.org/10.1021/jo00244a043

24. Zhu, Y.; Tu, Y.; Yu, H.; Shi, Y. Tetrahedron Lett. 1988, 29, 7819-7822.

25. Hashiyama, T.; Morikawa, K.; Sharpless, K. B. J. Org. Chem. 1992, 57, 5067-5068. https://doi.org/10.1021/jo00045a011

26. Stork, G.; Danheiser, R. L. J. Org. Chem. 1973, 38, 1775-1776. https://doi.org/10.1021/jo00949a048

27. Zhou, M.; Liu, T.-L.; Cao, M.; Xue, Z.; Lv, H.; Zhang, X. Org. Lett. 2014, 6, 3484-3487. https://doi.org/10.1021/ol501421g

28. Niyaz, N. M.; Bazin, B. Tetrahedron 2002, 58, 4879-4885. https://doi.org/10.1016/S0040-4020(02)00429-5

29. Banwell, M. G.; Jurya, J. C. Org. Prep. Proced. Int. 2004, 36, 87-91. https://doi.org/10.1080/00304940409355377

30. Compound 6 exhibits poor stability and undergoes decomposition upon standing at room temperature or during isolation via silica gel chromatography, which leads to decreased yields.

31. Herrick, E. C. U. S. Patent 2,964,526, 1960.

32. Oae, S.; Ohnishi, Y.; Kozuka, S.; Tagaki, W. Bull. Chem. Soc. Jpn. 1966, 39, 364-366. https://doi.org/10.1246/bcsj.39.364

33. Blair, L. K.; Baldwin, J.; Smith, W. C., Jr. J. Org. Chem. 1977, 42, 1816-1817. https://doi.org/10.1021/jo00430a038

34. Hypobromite $\mathbf{1 5}$ can be easily converted back to gem-dibromide $\mathbf{6}$ upon treatment with either a reducing reagent $\left(\mathrm{Na}_{2} \mathrm{~S}_{2} \mathrm{O}_{3}\right)$ or various bases (e.g. $\mathrm{LiOH}, \mathrm{NaOH}$, or $\mathrm{KOH}$ ).

35. This may be due to the electronic nature of vinylogous ester 6 which favors the formation of a conjugated $\mathrm{Y}$-anion stabilized through nucleophilic attack by the amide at a $\mathrm{Br}$ atom. Protonation of this dienolate during work-up would lead to mono-bromide 14.

36. For ${ }^{1} \mathrm{H},{ }^{13} \mathrm{C}, \mathrm{HMBC}$, and NOE spectra of compound $\mathbf{1 7}$, see the Supporting Information. 
37. Shepherd, R. G.; White, A. C. J. Chem. Soc., Perkin Trans. 1 1987, 2153-2156. https://doi.org/10.1039/P19870002153

38. Use of $\mathrm{NaH}$ or LiHMDS (at different temperatures) did not show any reaction. Use of LDA at $-78^{\circ} \mathrm{C}$ resulted in a very complicated reaction mixture. In all cases bromoacetonitrile was used as an alkylating reagent.

39. Pangborn, A. B.; Giardello, M. A.; Grubbs, R. H.; Rosen, R. K.; Timmers, F. J. Organometallics 1996, 15, 15181520.

https://doi.org/10.1021/om9503712

40. Still, W. C.; Kahn, M.; Mitra, A. J. Org. Chem. 1978, 43, 2923-2925. https://doi.org/10.1021/jo00408a041

41. The ${ }^{13} \mathrm{C}$ NMR of this compound exhibits extra signals that are not expected based on the product structure, although the ${ }^{1} \mathrm{H}$ HMR spectrum clearly corresponds to the product structure and does not reveal any unusual signals. 